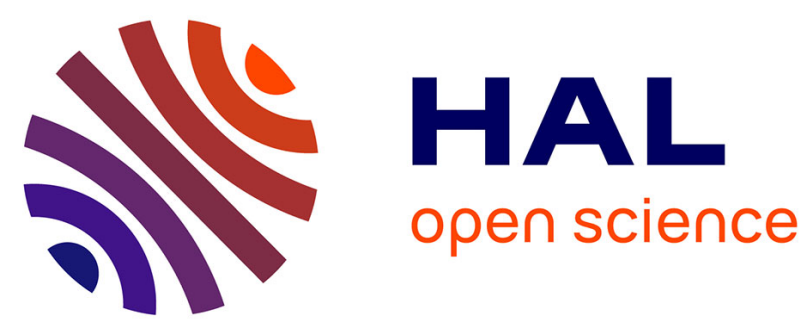

\title{
3D MAPPING OF ION VELOCITIES IN AN ECR PLASMA REACTOR BY LIF, DOPPLER SHIFT MEASUREMENTS
}

\author{
T. Nakano, J. Derouard, R. Gottscho, N. Sadeghi, D. Trever
}

\section{- To cite this version:}

T. Nakano, J. Derouard, R. Gottscho, N. Sadeghi, D. Trever. 3D MAPPING OF ION VELOCITIES IN AN ECR PLASMA REACTOR BY LIF, DOPPLER SHIFT MEASUREMENTS. Journal de Physique IV Proceedings, 1991, 01 (C7), pp.C7-560-C7-560. 10.1051/jp4:19917147 . jpa-00250821

HAL Id: jpa-00250821

https://hal.science/jpa-00250821

Submitted on 1 Jan 1991

HAL is a multi-disciplinary open access archive for the deposit and dissemination of scientific research documents, whether they are published or not. The documents may come from teaching and research institutions in France or abroad, or from public or private research centers.
L'archive ouverte pluridisciplinaire HAL, est destinée au dépôt et à la diffusion de documents scientifiques de niveau recherche, publiés ou non, émanant des établissements d'enseignement et de recherche français ou étrangers, des laboratoires publics ou privés. 


\title{
3D MAPPING OF ION VELOCITIES IN AN ECR PLASMA REACTOR BY LIF, DOPPLER SHIFT MEASUREMENTS
}

\author{
T. NAKANO, J. DEROUARD*, R.A. GOTTSCHO, N. SADEGHI ${ }^{*}$ and D.J. TREVER \\ AT \& T Bell Laboratories, Murray Hill, New Jersey 07974, USA \\ ${ }^{*}$ Laboratoire de Spectrométrie Physique ${ }^{(1)}$, Université Joseph-Fourier/Grenoble 1, \\ BP. 87, F-38402 Saint-Martin d'Hères cedex, France
}

Electron cyclotron resonance (ECR) is one of several plasma generation techniques that are being developed to overcome the Ultra Large Scale Integration (ULSI) constraints $(0.25 \mu \mathrm{m})$ in plasma processing of micro-electronic and photonic materials. To fully exploit the control offered by independent plasma generation in ECR reactors, it is necessary to understand how ions are formed and how they gain energy, and to know their velocity $\vec{v}$ at the wafer surface. Up to now, ion velocity distribution function (ivdf) measurements have been performed with Langmuir probes or by pinhole sampling electrostatic energy analysers. These methods are intrusive and are limited in angular resolution.

In this work, we have used non-intrusive laser induced fluorescence (LIF) for extensive memasurements of metastable argon ion, $\mathrm{Ar}^{+}\left(3 \mathrm{p}^{4} 3 \mathrm{~d}^{2} \mathrm{G} 9 / 2\right)$, velocity distributions both in an $\mathrm{ECR}$ source and in the reactor downstream from this source. Using a tunable, $\mathrm{cw}$ dye laser, three ivdfs : $v_{\mathrm{Z}}, \mathrm{v}_{\mathrm{r}}$ and $v_{\theta}$, are deduced from the Doppler shift in the LIF excitation spectrum and their variations as a function of magnetic field amplitude, microwave power, gas pressure and mixture, and R.F. bias voltage of the wafer have been studied.

Downstream, close to the wafer, we observe a bimodal ion velocity distribution : the fast component, created inside the source, follows magnetic flux lines into the reactor ; the slow component, created mostly where the plasma expands from the source into the reactor chamber, is more isotropic. The relative amplitudes of these two components, the average ion energy, and the ion energy distribution can be controlled by changing pressure and magnetic field. 